\title{
䪽口腔領域における多重癌の臨床的研究
}

\author{
田中 彰

\section{Clinical study of multiple primary cancers in the oral and maxillofacial region}

\begin{abstract}
Akira TANAKA
Abstract: A trend toward an increased incidence of multiple primary cancers has been reported. This report is consistent with this trend and describes the results of an investigation of patients registered at our hospital. Seventy-two patients with multiple primary cancers (7.8\% incidence) were identified among 927 patients with oral and maxillofacial cancers from January 1975 through December 1992.

In the former period (1975 to 1983) and the latter period (1984 to 1992), multiple primary cancers accounted for $5.4 \%$ and $10.2 \%$ of all oral and maxillofacial cancers, respectively. As for tumor site, the socalled multicentric zone, which includes the oral cavity, pharynx, larynx, esophagus, and lung, accounted for $68.3 \%$. Among 20 cases of synchronous occurrence, 9 subsequent cancers were detected in an early stage. However, among 26 cases of metachronous occurrence, 16 cases were in an advanced stage.

Smoking tobacco, alcohol intake, and familial history were also investigated as risk factors for malignancy. A family history was present in 23 patients $(31.9 \%)$, a smoking history in 47 patients $(65.3 \%)$, and a drinking history in 37 patients $(51.4 \%)$. The degrees of smoking and drinking were evaluated on the basis of Brinkman index and Sake index respectively. The mean Brinkman in the 72 patients was 486.7 , and the Sake index was 56.4. The mean average of Brinkman index in the smokers was 745.5, and the Sake index was 109.7. A high Brinkman index score was related to cancers of the oral floor and, soft palate, and a high Sake index score to cancers of the soft palate and esophagus.

Histologically, the incidence of squamous cell carcinoma was $65.2 \%$, and coincident squamous cell carcinomas were found in 31 patients $(43.1 \%)$.
\end{abstract}

Key words: oral and maxillofacial region (顎口腔領域), multiple primary cancer (多重癌), risk factor (危険因子), history of tobacco smoking (喫煙歴), history of drinking (飲酒歴)

緒

\section{言}

近年, 診断学の進歩に伴い, いわゆる多重癌が増加 する傾向にあり, なかでも顎口腔領域における多重癌 の発生頻度は，他領域に比較して高率とされてい る ${ }^{1 \sim 6)}$. 特に顎口腔領域, 呼吸器および上部消化管に

日本歯科大学新潟歯学部口腔外科学教室第二講座 （主任 : 又賀 泉教授）

Department of Oral and Maxillofacial Surgery II , School of Dentistry at Niigata, The Nippon Dental University (Chief: Prof. Izumi Mataga)

受付日：平成 7 年 10 月 23 日
おいては, 多中心性癌を高頻度に認める領域として知 られ $2 \sim 8)$, 積極的に第 2 癌の有無について精査をす べきであると提唱されている 2 11).

そこで顎口腔領域に発生した悪性腫瘍症例 927 例に 対し, retrospectiveな検索を行って多重癌症例を抽 出し, 臨床的検討を加えた。

\section{対象症例および検討方法}

\section{1. 対象症例}

対象は 1975 年 1 月 1 日より 1992 年 12 月 31 日の 18 年間に, 日本歯科大学新潟歯学部附属病院第 2 口腔外 
科および関連 4 医療施設を受診した顎口腔領域悪性腫 瘍患者 927 例のうち, 多重癌と診断された 72 例である. 本研究においては顎口腔領域を, 腫瘍の発生部位が解 剖学的に口腔および顎骨に発生したものに加え，耳下 腺, 顎下腺の大唾液腺, 上顎洞，口唇ならびに軟口蓋 を含めた領域とし, 顎口腔領域以外の領域に発生した ものを他領域として検討した。

\section{2 . 多重癌の定義}

重複癌の診断基準はWarren \& Gates ${ }^{12)}$ の定義に準

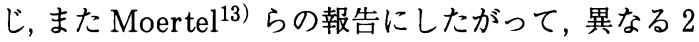
つ以上の臓器に腫瘍が発生した場合を重複癌, 同一臓器 内に複数個の腫瘍が発生した場合を多発癌として取り 扱うこととし，これらを総じて多重癌とした．多重癌の 構成は，顎口腔領域あるいは他領域のいずれかが癌腫で あることを条件とし, 癌腫と肉腫や悪性リンパ腫を含め た他の悪性腫瘍との組み合わせもこれに含めた. また剖 検により発見された潜在性の重複癌は対象から除外した.

さらに同一組織型癌腫の組み合わせでは, 再発, 転 移腫瘍との鑑別において, 臨床的に各腫瘍の連続性が ないと判断されたもので, 各腫县と正常粘膜上皮との 境界部あるいは腫湯の周囲組織への浸潤像を組織学的 に観察し，1）あきらかに臓器固有の粘膜上皮を発生
母地として周囲へ浸潤した所見を有し, 腫湯が上皮下 より増殖, 浸潤していないこと．2）各腫瘍の境界部 に，あきらかに正常粘膜上皮が介在していること.

を確認することにより判定した.

\section{3 . 口腔内多発癌の定義}

口腔粘膜に関しては解剖学的に複数の部位に発生し た癌で，同一組織型では臨床的に腫瘍の連続性がない と判断されたものに加え, 前述の組織学的判定基準を 満たしたものを口腔内多発癌と定義した。

口腔粘膜以外の他臓器内で発生した多発癌は, すべ て1つの癌とみなしたが, 原発性乳癌のうち対側乳腺 に発生したものは重複癌に含めた。

\section{4. 発生間隔について}

癌発生の時期はその診断日をもって発生したものと ᄂ, 第 1 癌 (先発癌) と第 2 癌 (後発癌) との発生間隔 が 6 か月以内のものを同時性, それ以上を異時性と定 義した. また診断日が同一なものは病期分類における 進行癌を先発癌と判断した。

\section{5. 多重癌の危険因子について}

多重癌発生の危険因子として，2 親等以内における 癌家族歴および喫煙歴, 飲酒歴からそれぞれ指数を算 定して検討した。喫煙歴は Brinkman index ${ }^{14}$ ）（1 日

表 1 多重癌発生頻度, 性別構成

\begin{tabular}{|c|c|c|c|c|c|}
\hline \multirow{2}{*}{ 年 } & \multicolumn{2}{|c|}{ 多重癌症例数 } & \multicolumn{2}{|c|}{ 全悪性腫瘍患者数 } & \multirow{2}{*}{$\begin{array}{c}\text { 発生頻度 } \\
\%\end{array}$} \\
\hline & 男 性 & 女性 & 男 性 & 女 性 & \\
\hline \multirow{2}{*}{1975} & \multicolumn{2}{|c|}{1} & \multicolumn{2}{|c|}{38} & \multirow{2}{*}{2.6} \\
\hline & 1 & 0 & 27 & 11 & \\
\hline \multirow{2}{*}{1976} & \multicolumn{2}{|c|}{2} & \multicolumn{2}{|c|}{56} & \multirow{2}{*}{3.6} \\
\hline & 2 & 0 & 30 & 26 & \\
\hline \multirow{2}{*}{1977} & \multicolumn{2}{|c|}{1} & \multicolumn{2}{|c|}{50} & \multirow{2}{*}{2.0} \\
\hline & 1 & 0 & 36 & 14 & \\
\hline \multirow{2}{*}{1978} & \multicolumn{2}{|c|}{3} & \multicolumn{2}{|c|}{53} & \multirow{2}{*}{5.7} \\
\hline & 3 & 0 & 36 & 17 & \\
\hline \multirow{2}{*}{1979} & \multicolumn{2}{|c|}{2} & \multicolumn{2}{|c|}{58} & \multirow{2}{*}{3.5} \\
\hline & 1 & 1 & 36 & 22 & \\
\hline \multirow{2}{*}{1980} & \multicolumn{2}{|c|}{3} & \multicolumn{2}{|c|}{50} & \multirow{2}{*}{6.0} \\
\hline & 2 & 1 & 34 & 16 & \\
\hline \multirow{2}{*}{1981} & \multicolumn{2}{|c|}{2} & \multicolumn{2}{|c|}{51} & \multirow{2}{*}{3.9} \\
\hline & 2 & 0 & 34 & 17 & \\
\hline \multirow{2}{*}{1982} & \multicolumn{2}{|c|}{6} & \multicolumn{2}{|c|}{58} & $10 ?$ \\
\hline & 5 & 1 & 39 & 19 & 10.3 \\
\hline 1 & & & & & 06 \\
\hline 1983 & 3 & 2 & 36 & 16 & 9.6 \\
\hline 小計 & & & & & \\
\hline 小計 & 20 & 5 & 308 & 158 & 5.4 \\
\hline
\end{tabular}

\begin{tabular}{|c|c|c|c|c|c|}
\hline \multirow{2}{*}{ 年 } & \multicolumn{2}{|c|}{ 多重癌症例数 } & \multicolumn{2}{|c|}{ 全覀性腫瘍患者数 } & \multirow{2}{*}{$\begin{array}{c}\text { 発生頻度 } \\
\%\end{array}$} \\
\hline & 男 性 & 女性 & 男 性 & 女 性 & \\
\hline \multirow{2}{*}{1984} & \multicolumn{2}{|c|}{2} & \multicolumn{2}{|c|}{62} & \multirow{2}{*}{3.2} \\
\hline & 2 & 0 & 38 & 24 & \\
\hline \multirow{2}{*}{1985} & \multicolumn{2}{|c|}{3} & \multicolumn{2}{|c|}{35} & \multirow{2}{*}{8.6} \\
\hline & 3 & 0 & 26 & 9 & \\
\hline \multirow{2}{*}{1986} & \multicolumn{2}{|c|}{12} & \multicolumn{2}{|c|}{41} & \multirow{2}{*}{29.3} \\
\hline & 6 & 6 & 30 & 11 & \\
\hline \multirow{2}{*}{1987} & \multicolumn{2}{|c|}{3} & \multicolumn{2}{|c|}{52} & \multirow{2}{*}{5.7} \\
\hline & 2 & 1 & 40 & 12 & \\
\hline \multirow{2}{*}{1988} & \multicolumn{2}{|c|}{3} & \multicolumn{2}{|c|}{57} & \multirow{2}{*}{5.3} \\
\hline & 3 & 0 & 38 & 19 & \\
\hline \multirow{2}{*}{1989} & \multicolumn{2}{|c|}{8} & \multicolumn{2}{|c|}{50} & \multirow{2}{*}{16.0} \\
\hline & 5 & 3 & 39 & 11 & \\
\hline \multirow{2}{*}{1990} & \multicolumn{2}{|c|}{6} & \multicolumn{2}{|c|}{66} & \multirow{2}{*}{9.1} \\
\hline & 6 & 0 & 46 & 20 & \\
\hline \multirow{2}{*}{1991} & \multicolumn{2}{|c|}{8} & \multicolumn{2}{|c|}{46} & 17 \\
\hline & 6 & 2 & 26 & 20 & 11.4 \\
\hline 1992 & & & & & 39 \\
\hline & 1 & 1 & 25 & 27 & 0.5 \\
\hline 小計 & & & & & 10? \\
\hline 小陑 & 34 & 13 & 308 & 153 & 10.4 \\
\hline
\end{tabular}

多重癌発生頻度 $7.8 \%$ (72 例 $/ 927$ 例) 


\begin{tabular}{|c|c|}
\hline 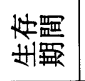 & 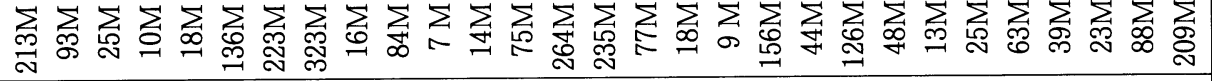 \\
\hline 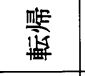 & 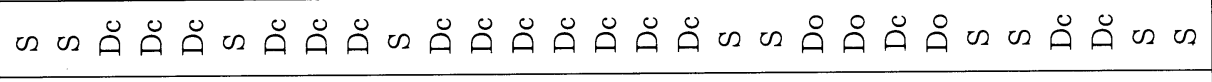 \\
\hline$\stackrel{*}{*}$ & ภㅇ ก \\
\hline$\stackrel{*}{\oplus} \stackrel{0}{\oplus}$ & 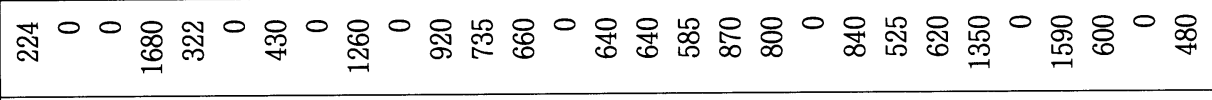 \\
\hline 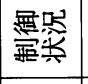 & 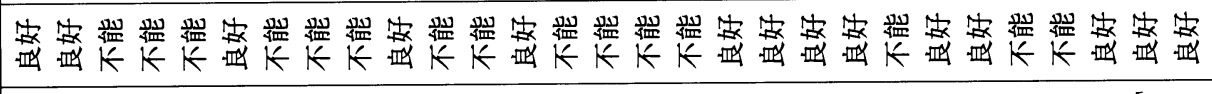 \\
\hline 煰 & 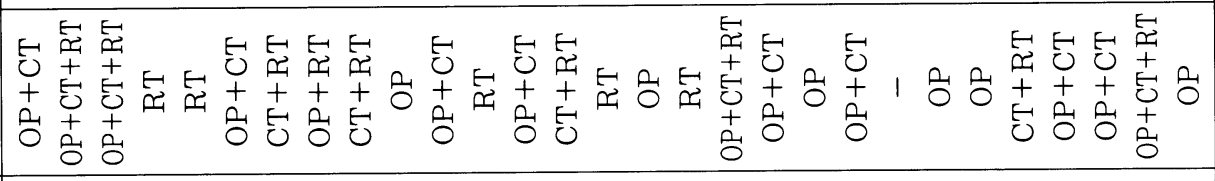 \\
\hline 紫 & 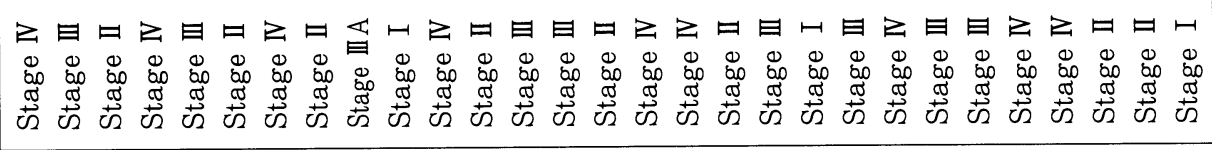 \\
\hline 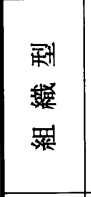 & 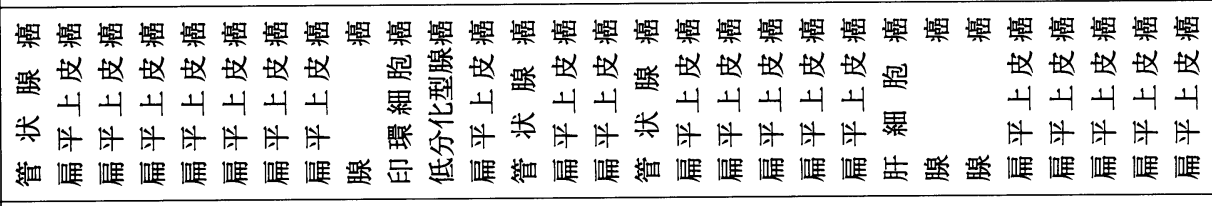 \\
\hline 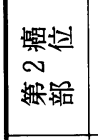 & 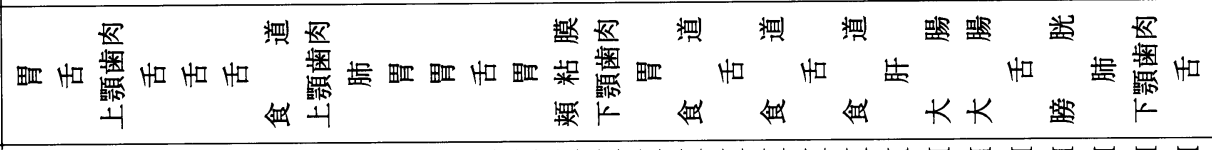 \\
\hline 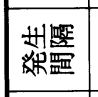 & 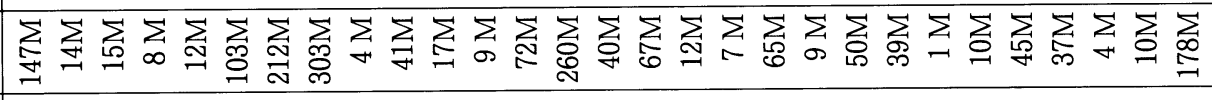 \\
\hline 逪哭 & 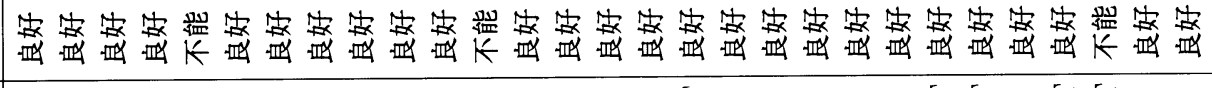 \\
\hline 管 & 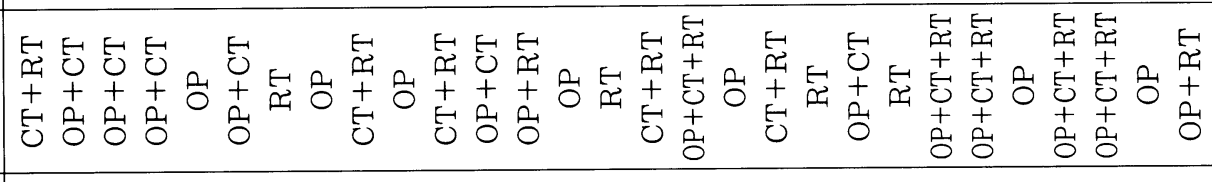 \\
\hline 紫 & 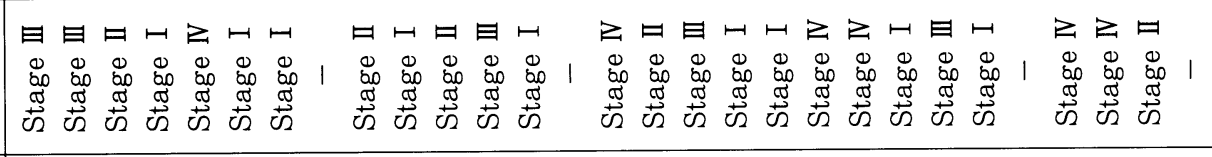 \\
\hline 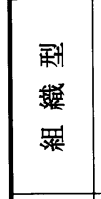 & 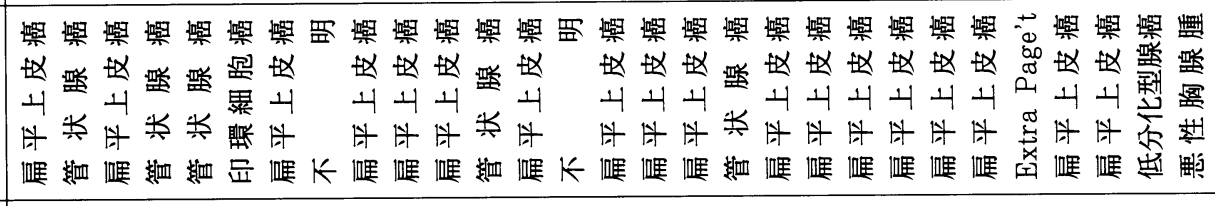 \\
\hline 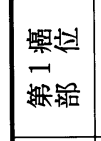 & 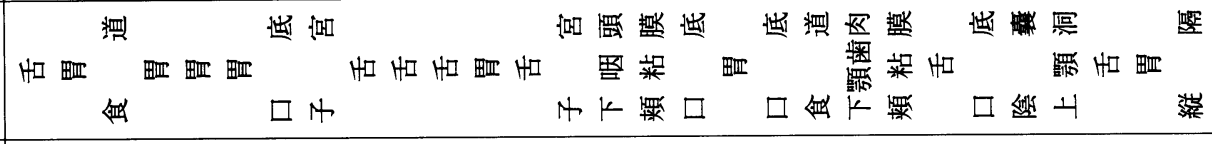 \\
\hline 幽踇 & 戠 \\
\hline$\$$ & 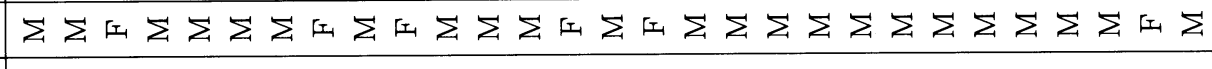 \\
\hline 葸吅 & $v$ \\
\hline
\end{tabular}




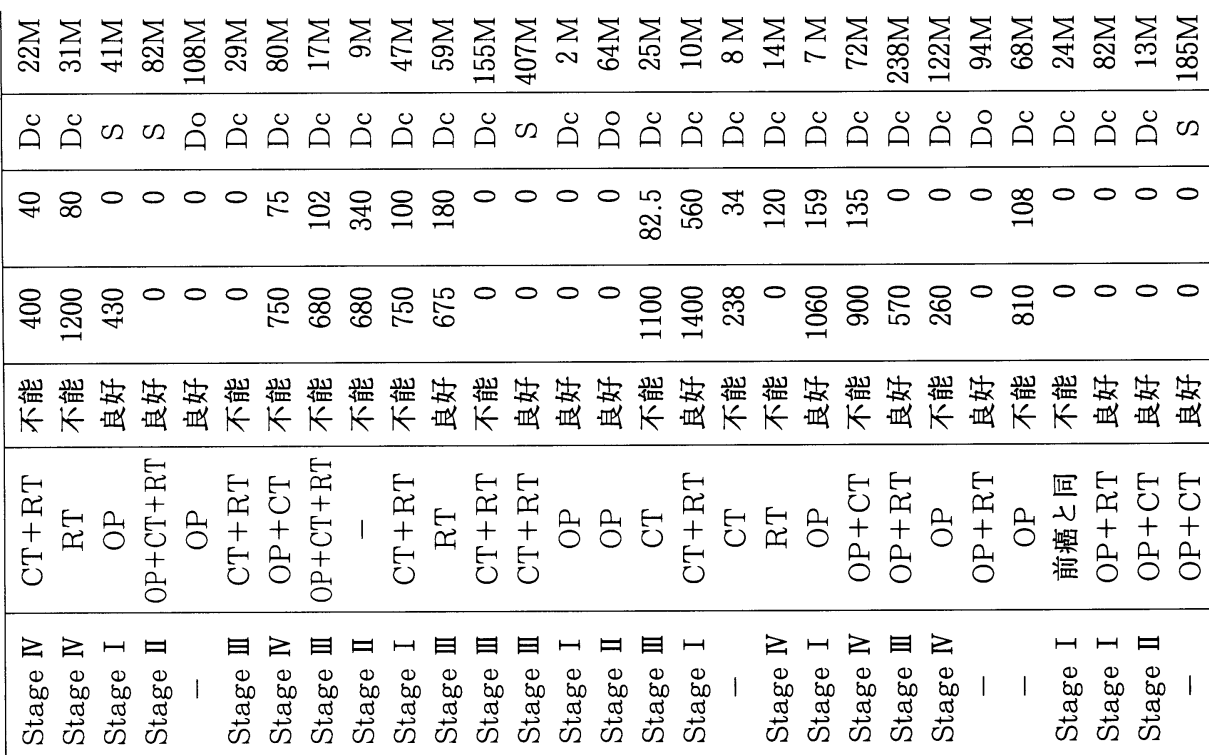

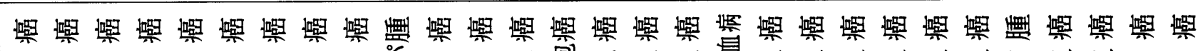

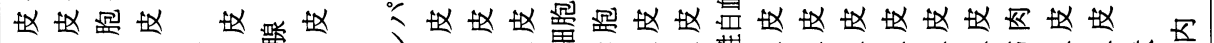

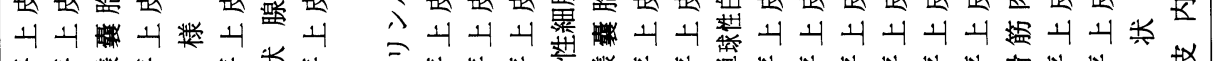

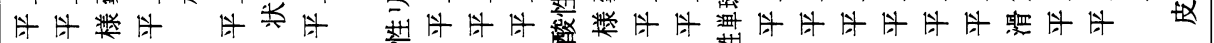

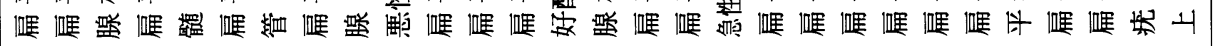

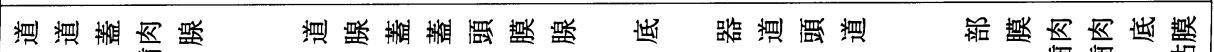

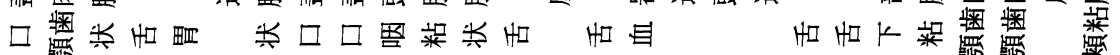

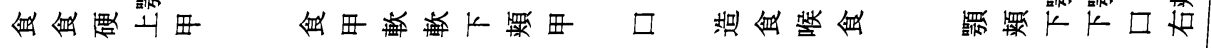

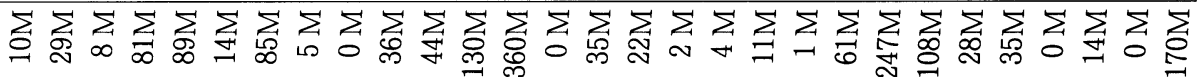

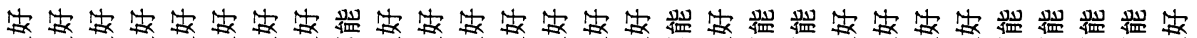

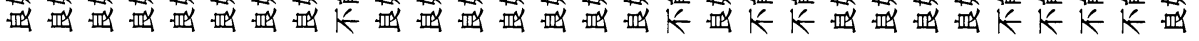
湈 U2 崖 踭 ○装 罂 憵 然 䣃 管迦 수 $x$

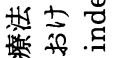
浆苛 篮长 慗* 茫 "N ผู ชิ

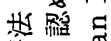

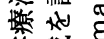
非

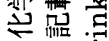
少 包 $\gtrsim$ +o d H要. 究 紧

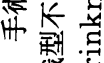
号篮

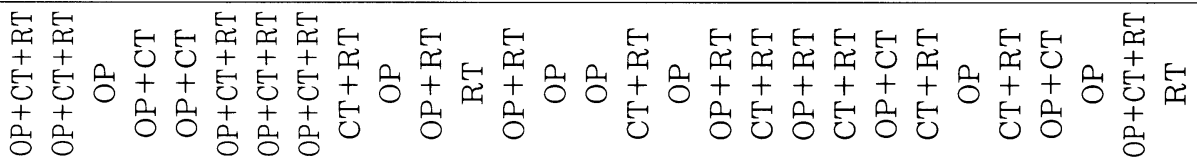

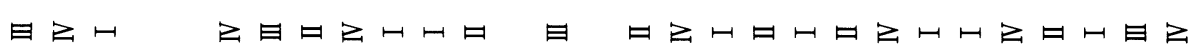

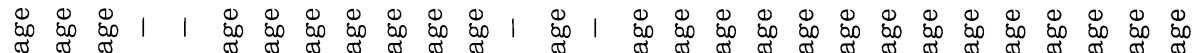

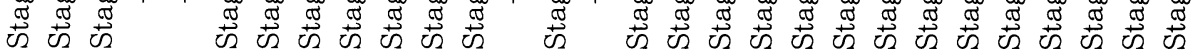

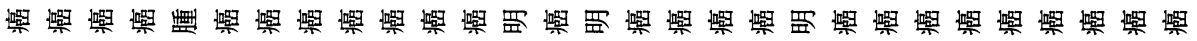

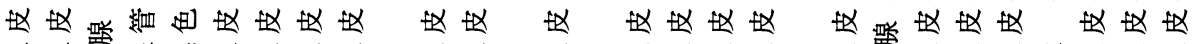

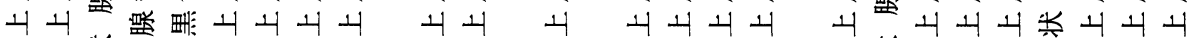

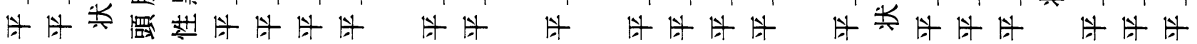

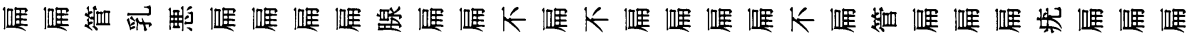

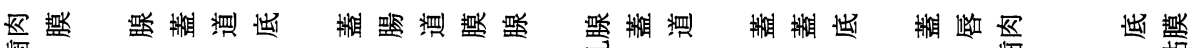

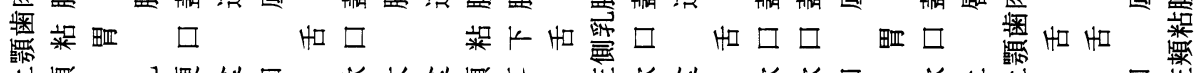

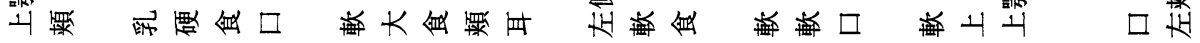

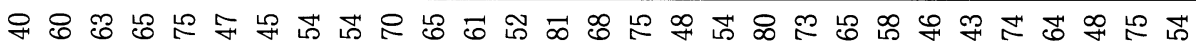

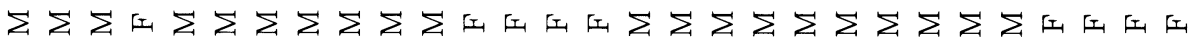
闹 


\begin{tabular}{|c|c|c|c|c|c|c|c|c|c|c|c|c|}
\hline $\begin{array}{l}\text { 筒 } \\
\text { 覀 }\end{array}$ & $\sum_{\text {f }}$ & $\sum_{\underline{E}}^{ \pm}$ & $\sum_{8}$ & 主 & 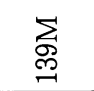 & 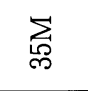 & $\sum_{\text {N }}$ & 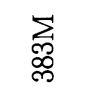 & 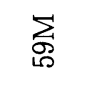 & $\underset{⿱ 亠}{\vdots}$ & $\sum_{\infty}^{\infty}$ & \multirow{18}{*}{ 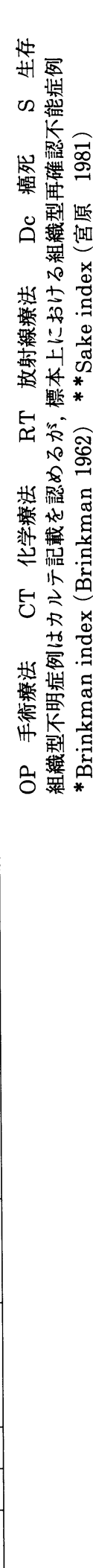 } \\
\hline 歪 & Ö & $\ddot{A}$ & ڤ̊ & U & ค̊ & ̊̊ & $\omega$ & $\omega$ & 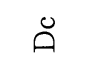 & Ø̊ & $\ddot{A}$ & \\
\hline 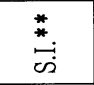 & ชิ & $\stackrel{\infty}{+}$ & $\mathscr{F}$ & 0 & 0 & $\overrightarrow{5}$ & $\cong$ & 0 & ষ্ণ & §ิ & $\dddot{F}$ & \\
\hline$\stackrel{*}{*}$ & ণิ & 导 & 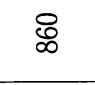 & 0 & 0 & 음 & 0 & 伿 & 笒 & \&్రి & 里 & \\
\hline 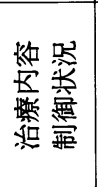 & 号䋊 & 㤎察 & 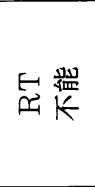 & 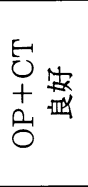 & 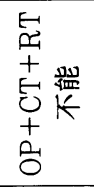 & 它艪 & 员察 & $\begin{array}{l}\text { 㫐 } \\
+ \text { 它 } \\
D_{0}\end{array}$ & 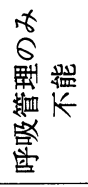 & 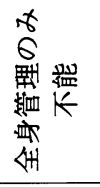 & 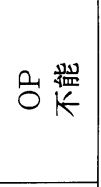 & \\
\hline $\begin{array}{l}\text { 霊 } \\
\text { 紫 }\end{array}$ & $\begin{array}{l}\text { 目 } \\
0 \\
\infty \\
\sigma \\
\Phi \\
\omega\end{array}$ & $\begin{array}{l}\text { 目 } \\
0 \\
\infty \\
\Phi \\
\infty \\
\omega\end{array}$ & 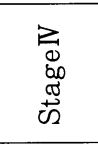 & $\begin{array}{l}\varangle \\
\boxminus \\
0 \\
\infty \\
\Phi \\
\pm \\
0 \\
0\end{array}$ & $\begin{array}{l}10 \\
0 \\
\infty \\
\Phi \\
0 \\
0\end{array}$ & 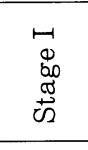 & 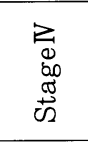 & $\begin{array}{l}= \\
0 \\
\infty \\
\infty \\
\tilde{D} \\
0\end{array}$ & 1 & 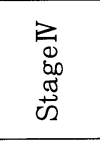 & 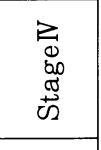 & \\
\hline 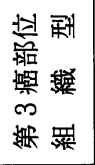 & 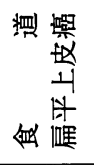 & 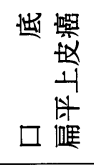 & 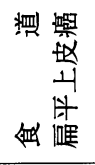 & 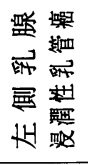 & 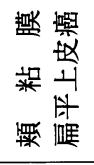 & 毗 & 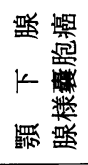 & 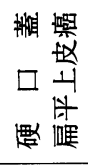 & 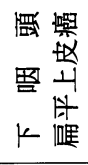 & 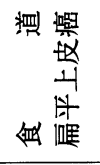 & 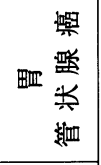 & \\
\hline 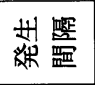 & $\sum_{=}$ & $\sum_{0}$ & 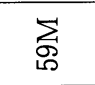 & 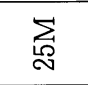 & $\sum_{\exists}$ & $\sum_{\infty}^{\infty}$ & 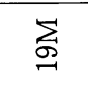 & $\sum_{\infty}$ & $\sum_{0}$ & 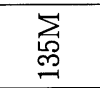 & $\underset{\Xi}{\Sigma}$ & \\
\hline 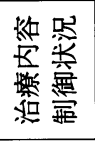 & 灾察 & 吕鯊 & 号察 & 号察 & 㤎察 & 客菑 & 点蜜 & 号察 & 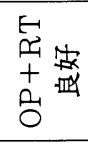 & 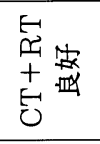 & 兒辒 & \\
\hline $\begin{array}{l}\text { 狦 } \\
\text { 紫 }\end{array}$ & 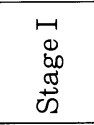 & $\begin{array}{l}0 \\
\infty \\
\infty \\
\Phi \\
0 \\
0\end{array}$ & 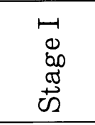 & $\begin{array}{l}w \\
0 \\
00 \\
\Phi \\
0 \\
0 \\
0\end{array}$ & $\begin{array}{l}3 \\
0 \\
\infty \\
\infty \\
0 \\
01 \\
0\end{array}$ & $\begin{array}{l}w \\
0 \\
\infty \\
\Phi \\
\mathbb{0} \\
0\end{array}$ & $\begin{array}{l}W \\
0 \\
\infty \\
\Phi \\
\Phi \\
0\end{array}$ & 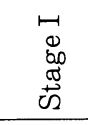 & $\begin{array}{l}\text { 目 } \\
0 \\
\infty \\
\infty \\
0 \\
0\end{array}$ & $\begin{array}{l}10 \\
0 \\
00 \\
\Phi \\
0 \\
0\end{array}$ & 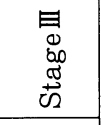 & \\
\hline 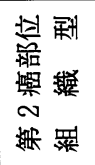 & 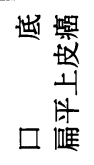 & 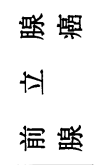 & 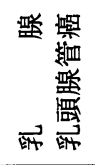 & 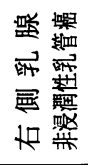 & 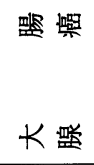 & 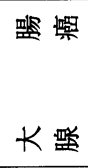 & 毗觜 & 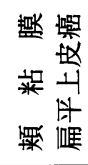 & 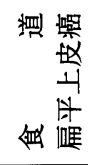 & 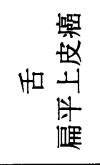 & 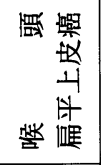 & \\
\hline 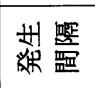 & 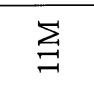 & 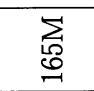 & $\sum_{\infty}$ & $\Sigma_{0}$ & $\sum_{\infty}$ & $\sum_{N}$ & $\sum_{N}$ & 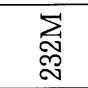 & $\sum_{\substack{+1 \\
+1}}$ & 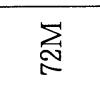 & $\sum_{\substack{D \\
\text { 足 }}}$ & \\
\hline 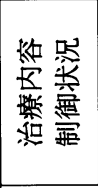 & 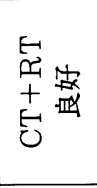 & 它诺 & 点蜜 & 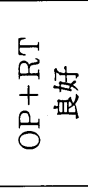 & 号察 & 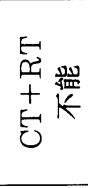 & 它密 & 架密 & 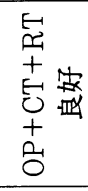 & 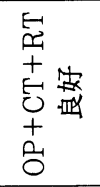 & 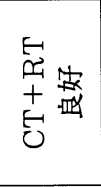 & \\
\hline $\begin{array}{l}\text { 需 } \\
\text { 紫 }\end{array}$ & 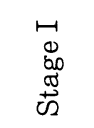 & 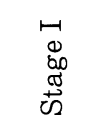 & $\begin{array}{l}\text { ज } \\
0 \\
\infty \\
\Phi \\
0 \\
0\end{array}$ & 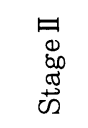 & $\begin{array}{l}\varpi \\
0 \\
\infty \\
\Phi \\
\tilde{D}\end{array}$ & 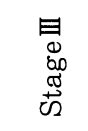 & 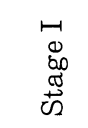 & 1 & 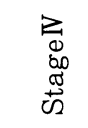 & 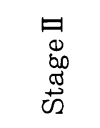 & 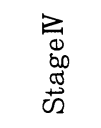 & \\
\hline 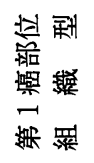 & 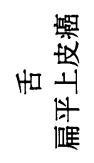 & 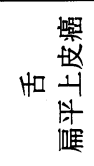 & 吅望 & 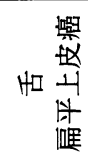 & 鮞觜 & 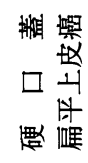 & 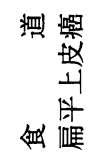 & 酱贯 & 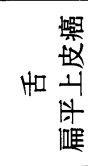 & 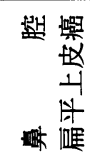 & 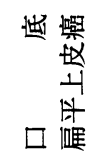 & \\
\hline स 经 & 도 & 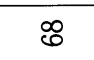 & ஜ & \& & 8 & $E$ & 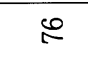 & is & $\mathscr{F}$ & 范 & $\mathscr{\varnothing}$ & \\
\hline *H & $\Sigma$ & $\Sigma$ & ⿷匚 & ⿷匚 & 压 & $\Sigma$ & $\Sigma$ & $\Sigma$ & $\Sigma$ & $\Sigma$ & $\Sigma$ & \\
\hline $\begin{array}{l}\text { 罴吅 } \\
\text { 腘 }\end{array}$ & 용 & 8 & $\overline{6}$ & กิ & ஜ & 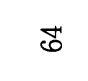 & 농 & 8 & $\widehat{6}$ & $\infty$ & 8 & \\
\hline
\end{tabular}


表 4 四重癌症例一覧

\begin{tabular}{|c|c|c|c|c|c|c|c|c|c|}
\hline $\begin{array}{l}\text { 症例 } \\
\text { 番号 }\end{array}$ & $\begin{array}{c}\text { 性 } \\
\text { 年齢 }\end{array}$ & $\begin{array}{l}\text { 第 } 1 \text { 癌部位 } \\
\text { 組 織 型 }\end{array}$ & 病 期 & $\begin{array}{l}\text { 治療内容 } \\
\text { 制御状況 }\end{array}$ & $\begin{array}{l}\text { 発生 } \\
\text { 間隔 }\end{array}$ & $\begin{array}{l}\text { 第 } 2 \text { 癌部位 } \\
\text { 組 } \\
\text { 織 型 }\end{array}$ & 病 期 & $\begin{array}{l}\text { 治療内容 } \\
\text { 制御状況 }\end{array}$ & $\begin{array}{l}\text { 発生 } \\
\text { 間隔 }\end{array}$ \\
\hline 70 & $\begin{array}{l}\mathrm{M} \\
58\end{array}$ & $\begin{array}{l}\text { 口底 } \\
\text { 扁平上皮癌 }\end{array}$ & StageIV & $\begin{array}{l}\mathrm{CT}+\mathrm{RT} \\
\text { 不能 }\end{array}$ & $0 \mathrm{M}$ & $\begin{array}{l}\text { 下 咽 頭 } \\
\text { 扁平上皮癌 }\end{array}$ & Stage III & $\begin{array}{c}\mathrm{CT}+\mathrm{RT} \\
\text { 不能 }\end{array}$ & $1 \mathrm{M}$ \\
\hline 71 & $\begin{array}{l}\mathrm{M} \\
57\end{array}$ & $\begin{array}{c}\text { 肺 } \\
\text { 低分化型腺癌 }\end{array}$ & Stage I & $\begin{array}{c}\mathrm{OP}+\mathrm{CT} \\
\text { 良好 }\end{array}$ & $8 \mathrm{M}$ & $\begin{array}{l}\text { 下 咽 頭 } \\
\text { 扁平上皮癌 }\end{array}$ & Stage III & $\begin{array}{c}\mathrm{OP}+\mathrm{CT}+\mathrm{RT} \\
\text { 良好 }\end{array}$ & $34 \mathrm{M}$ \\
\hline 72 & $\begin{array}{l}\mathrm{M} \\
51\end{array}$ & $\begin{array}{l}\text { 大 } \\
\text { 腺 }\end{array}$ & - & $\begin{array}{l}\mathrm{OP} \\
\text { 良好 }\end{array}$ & $97 \mathrm{M}$ & $\begin{array}{c}\text { 胃 } \\
\text { 管 状腺 癌 }\end{array}$ & - & $\begin{array}{l}\text { OP } \\
\text { 良好 }\end{array}$ & $86 \mathrm{M}$ \\
\hline
\end{tabular}

\begin{tabular}{|c|c|c|c|c|c|c|c|c|c|c|}
\hline $\begin{array}{l}\text { 症例 } \\
\text { 番号 }\end{array}$ & $\begin{array}{l}\text { 第 } 3 \text { 癌部位 } \\
\text { 組 織 型 }\end{array}$ & 病 期 & $\begin{array}{l}\text { 治療内容 } \\
\text { 制御状況 }\end{array}$ & $\begin{array}{l}\text { 発生 } \\
\text { 間隔 }\end{array}$ & $\begin{array}{l}\text { 第 } 4 \text { 癌部位 } \\
\text { 組 }\end{array}$ & 病 期 & $\begin{array}{l}\text { 治療内容 } \\
\text { 制御状況 }\end{array}$ & B.I.* & S.I.*** & $\begin{array}{l}\text { 転 㷌 } \\
\text { 生存期間 }\end{array}$ \\
\hline 70 & $\begin{array}{l}\text { 食道 } \\
\text { 扁平上皮癌 }\end{array}$ & Stage I & $\begin{array}{c}\mathrm{CT}+\mathrm{RT} \\
\text { 不能 }\end{array}$ & $2 \mathrm{M}$ & $\begin{array}{c}\text { 胃 } \\
\text { 管状腺 癌 }\end{array}$ & Stage I & $\begin{array}{l}- \\
\text { 不能 }\end{array}$ & 570 & 152 & $\begin{array}{l}\mathrm{Dc} \\
6 \mathrm{M}\end{array}$ \\
\hline 71 & $\begin{array}{l}\text { 口底 } \\
\text { 扁平上皮癌 }\end{array}$ & Stage III & $\begin{array}{c}\mathrm{OP}+\mathrm{CT}+\mathrm{RT} \\
\text { 良好 }\end{array}$ & $12 \mathrm{M}$ & $\begin{array}{lr}\text { 食道 } \\
\text { 扁平上皮癌 }\end{array}$ & Stage IV & $\begin{array}{c}\mathrm{CT}+\mathrm{RT} \\
\text { 不能 }\end{array}$ & 740 & 74 & $\begin{array}{c}\mathrm{Dc} \\
69 \mathrm{M}\end{array}$ \\
\hline 72 & $\begin{array}{l}\text { 頪 粘 膜 } \\
\text { 扁平上皮癌 }\end{array}$ & StageIV & $\begin{array}{c}\mathrm{OP}+\mathrm{CT}+\mathrm{RT} \\
\text { 良好 }\end{array}$ & $53 \mathrm{M}$ & $\begin{array}{l}\text { 耳 } \quad \text { 腺 } \\
\text { 乳頭状腺癌 }\end{array}$ & Stage I & $\begin{array}{l}\text { OP } \\
\text { 良好 }\end{array}$ & 310 & 0 & $\begin{array}{c}\mathrm{S} \\
259 \mathrm{M}\end{array}$ \\
\hline
\end{tabular}

OP 手術療法 CT 化学療法 RT 放射線療法 Dc 癌死 $\mathrm{S}$ 生存

*Brinkman index (Brinkman 1962) **Sake index（宮原 1981）

乫煙本数 $\times$ 喫煙年数)を, 飲酒歷は Sake index ${ }^{15 ）(日 ~}$ 本酒換算 1 日飲酒合数 $\times$ 飲酒年数) を指標として評価 した.

\section{結果}

\section{1. 発生頻度, 性別}

多重癌の発生頻度すなわち対象とした全悪性腫場患 者総数 927 例に占める割合は 72 例, $7.8 \%$ であった. ま た経年的な多重癌の発生頻度を年次的に比較すること を目的に, 対象期間における前半の 9 年間（1975 年〜 1983 年) を前期とし, 後半の 9 年間（1984 年～1992 年） を後期とすると，その発生頻度はそれぞれ $5.4 \%(25$ 例 $/ 466$ 例) および $10.2 \%$ (47 例/ 461 例) であった.

性別では，全悪性腫湯患者においては男性 616 例 (66.5\%) に対し，女性が 311 例（33.5\%）であったの に対し, 多重癌症例においては男性 54 例 (75.0\%), 女 性 18 例（25.0\%）であった. 年次的に性別頻度を比較 すると，前期では全悪性腫湯患者において，男性 308 例 $(66.1 \%)$ ，女性が 158 例（33.9\%）であったのに対 し, 多重癌症例においては男性 20 例 $(75.0 \%)$, 女性 5 例 $(25.0 \%)$ で, 後期では全悪性腫瘍患者において, 男 性 308 例 (66.8\%)，女性が 153 例（33.2\%）であったの
に対し, 多重癌症例においては男性 34 例 $(72.3 \%)$, 女 性 13 例（27.7\%）であった（表 1 ）.

多重癌症例 72 例は 72 部位の第 1 癌に対する 89 部 位の後発癌, 延べ 161 部位の悪性腫瘍で構成され，そ の内訳は, 二重癌 58 例 $(80.5 \%)$, 三重癌 11 例 (15.3\%), 四重癌 3 例 $(4.2 \%)$ であった. 二重癌におい ては, 顎口腔領域と他領域との組み合わせが 49 例 (84.5\%), 顎口腔領域に重複した腫瘍が 9 例 (15.5\%) で, このうち口腔内多発癌が 4 例 $(6.9 \%)$, 口腔以外の 顎口腔領域に発生した癌の組み合わせが 5 例 (8.6\%) であった. また顎口腔領域と他領域の組み合わせにお いては, 顎口腔領域を先発癌とじたものが 27 例 (55.1 $\%)$, 後発癌が 22 例 (44.9\%) であった（表 2〜4）.

\section{2. 年齢}

多重癌とみなした第 2 癌発生時における年齢は, 平 均 64.8 歳であった. 年次的には, 前期においては平均 58.2 歳で, 後期においては平均 63.3 歳であった（表 5 ).

\section{3 . 発生部位と順序について}

多重癌の発生部位は, 顎口腔領域では舌が 32 部位 (37.6\%) で最も多く, 次いで口底 14 部位 $(16.5 \%)$, 煩 粘膜 12 部位 $(14.1 \%)$, 軟口蓋 7 部位 $(8.2 \%)$, 上䫟歯 肉, 下䫟歯肉がそれぞれ 5 部位 $(5.9 \%)$, 硬口蓋 4 部位 
表 5 年齢構成

\begin{tabular}{ccc}
\hline 年代別 多重癌発生 (第 2 癌発生時) 平均年齢 \\
& $1975 \sim 1983$ & 58.2 歳 \\
$1984 \sim 1992$ & 63.4 歳 \\
全体 & 64.8 歳
\end{tabular}

表 6 発生部位別頻度

\begin{tabular}{|c|c|c|c|c|c|c|}
\hline 部 & 位 & 第 1 癌 & 第 2 癌 & 第 3 癌 & 第 4 癌 & 計 \\
\hline \multirow[t]{12}{*}{ 顎口腔領域 } & 舌 & 17 & 15 & 0 & 0 & 32 \\
\hline & 口底 & 9 & 3 & 2 & 0 & 14 \\
\hline & 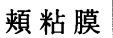 & 5 & 5 & 2 & 0 & 12 \\
\hline & 軟口蓋 & 5 & 2 & 0 & 0 & 7 \\
\hline & 上頼歯肉 & 2 & 3 & 0 & 0 & 5 \\
\hline & 下頻歯肉 & 1 & 4 & 0 & 0 & 5 \\
\hline & 硬口蓋 & 2 & 1 & 1 & 0 & 4 \\
\hline & 耳下腺 & 1 & 0 & 0 & 1 & 2 \\
\hline & 顎下腺 & 0 & 0 & 1 & 0 & 1 \\
\hline & 上顎洞 & 1 & 0 & 0 & 0 & 1 \\
\hline & 上 唇 & 1 & 0 & 0 & 0 & 1 \\
\hline & 顎下部 & 0 & 1 & 0 & 0 & 1 \\
\hline \multirow[t]{17}{*}{ 他領域 } & 胃 & 10 & 8 & 2 & 1 & 21 \\
\hline & 食 道 & 6 & 10 & 4 & 1 & 21 \\
\hline & 大 腸 & 2 & 4 & 0 & 0 & 6 \\
\hline & 下咽頭 & 1 & 3 & 1 & 0 & 5 \\
\hline & 乳 腺 & 2 & 2 & 1 & 0 & 5 \\
\hline & 肺 & 1 & 2 & 0 & 0 & 3 \\
\hline & 甲状腺 & 0 & 3 & 0 & 0 & 3 \\
\hline & 子 宮 & 2 & 0 & 0 & 0 & 2 \\
\hline & 喉 頭 & 0 & 2 & 0 & 0 & 2 \\
\hline & 膀 胱 & 1 & 1 & 0 & 0 & 2 \\
\hline & 前立腺 & 0 & 1 & 0 & 0 & 1 \\
\hline & 肝 & 0 & 1 & 0 & 0 & 1 \\
\hline & 陰＼cjkstart㤟 & 1 & 0 & 0 & 0 & 1 \\
\hline & 縦 隔 & 1 & 0 & 0 & 0 & 1 \\
\hline & 鼻 腔 & 1 & 0 & 0 & 0 & 1 \\
\hline & 造血器 & 0 & 1 & 0 & 0 & 1 \\
\hline & 計 & 72 & 72 & 14 & 3 & 161 \\
\hline
\end{tabular}

表 7 発生部位組み合わせ

\begin{tabular}{|c|c|c|c|}
\hline \multicolumn{2}{|c|}{ 先 発 癌 } & 後 発 癌 & 組み合わせ総数 \\
\hline \multicolumn{2}{|c|}{ 胃 } & 舌 & 7 \\
\hline \multicolumn{2}{|c|}{ 舌 } & 胃 & 4 \\
\hline 口 & 底 & 食 & 4 \\
\hline 食 & 道 & 舌 & 3 \\
\hline \multicolumn{2}{|c|}{ 舌 } & 肺 & 2 \\
\hline \multicolumn{2}{|c|}{ 舌 } & 下顎歯肉 & 2 \\
\hline
\end{tabular}

$(4.7 \%)$ ，耳下腺 2 部位（2.3\%)，以下顎下腺，上顎洞， 上唇, 䪽下部がそれぞれ 1 部位 $(1.2 \%)$ であった。ま た他領域では胃, 食道などの上部消化管がそれぞれ 21 部位 (各 27.6\%) で最も多く，次いで大腸癌が 6 部位 (7.9\%), 下咽頭, 乳腺がそれぞれ 5 部位 $(6.6 \%)$, 肺, 甲状腺がそれぞれ 3 部位 $(3.9 \%)$, 子宮, 喉頭, 膀胱が それぞれ 2 部位 $(2.6 \%)$, 前立腺, 肝, 陰囊, 縦隔, 鼻 腔, 造血器がそれぞれ 1 部位 (1.3\%) であった。

発生順序は, 第 1 癌として舌が 17 部位 $(23.6 \%)$ で 最も多く，次いで胃が 10 部位 $(13.9 \%)$, 口底 9 部位 (12.5\%), 食道 6 部位 $(8.3 \%)$, 煩粘膜, 軟口蓋がそれ ぞれ 5 部位 (各 6.9\%) であった. 第 2 癌としては舌が 15 部位 $(20.8 \%)$ で最も多く, 次いで食道が 10 部位 (13.9\%), 胃 8 部位 $(11.1 \%)$, 煩粘膜 5 部位 $(6.9 \%)$, 下顎歯肉, 大腸がそれぞれ 4 部位 $(5.6 \%)$ であった. さらに第 3 癌以上では食道が 5 部位 $(29.4 \%)$ で最も 多く, 次いで胃が 3 部位 $(17.6 \%)$, 口底, 煩粘膜がそ れぞれ 2 部位 (11.8\%) であった．また舌は 32 部位す べてが第 1 癌, 第 2 癌として発生しており, 軟口蓋, 上 顎歯肉, 下顎歯肉, 大腸, 肺, 甲状腺, 子宮, 喉頭, 膀胱 も同様であった. 一方, 食道は第 2 癌以上の発生が 15 部位 (71.4\%) と多かった（表 6 ).

先発癌と後発癌の臓器別の組み合わせは, 胃と舌の 組み合わせが 7 例と最も多く, 次いで舌と胃, 口底と 食道がそれぞれ 4 例, 食道と舌が 3 例, 舌と肺, 舌と下 顎歯肉がそれぞれ 2 例であった（表 7 ).

\section{4. 発生間隔, 病期進行度}

多重癌の発生間隔については, 二重癌において 6 か 月以内に第 2 癌が診断された同時性が 11 例, $7 \sim 12$ か月が 11 例, 13〜 24 か月が 6 例, 25 60 か月が 12 例, 61 か月以上が 18 例であった. 最短は同日，最長は 360 か月後に診断されたもので, 平均は 59.0 か月であった. また三重癌では第 1 癌と第 2 癌の間隔において同時性 が 3 例, $7 \sim 12$ か月が 1 例, $25 \sim 60$ か月が 3 例, 61 か 月以上が 4 例であり, 最短 20 日, 最長 232 か月, 平均 64.1 か月であった. さらに第 2 癌と第 3 癌の間隔では 6 か月以内の同時性が 3 例, 13 24 か月が 3 例, 25 60 か月が 3 例, 61 か月以上は 2 例であり, 最短 1 か月, 最長 135 か月, 平均発生間隔は 37.3 か月であった。 四 重癌では第 1 癌と第 2 癌の平均発生間隔は 35.0 か月, 第 2 癌と第 3 癌では 40.3 か月, 第 3 癌と第 4 癌は 22.3 か月であった. また同時性四重癌が 1 例あり，それぞ れの発生間隔は, 同日, 1 か月, 2 か月であった (表 8 ).

発生間隔と全多重癌症例 72 例の後発癌 89 部位 (第 3 癌, 第 4 癌含む) の病期について検討すると， 6 か月 以内の同時性では Stage I が 9 部位 (45.0\%), Stage II 3 部位 $(15.0 \%)$, Stage III 5 部位 $(25.0 \%)$, Stage IV は 1 部位（5.0\%）であった。また 7〜12 か月は Stage I , II，四がそれぞれ 3 部位 $(21.4 \%)$, Stage IV は 5 部位 $(35.8 \%)$ であった.さらに 61 か月以上では 
表 8 発 生 間 隔

\begin{tabular}{|c|c|c|c|c|c|}
\hline 二重癌 & 発生間隔（月） & 第 1 癌－第 2 癌（例） & 計 (症例数) & & \\
\hline \multirow[t]{6}{*}{$\mathrm{n}=58$} & $0-6$ & 11 & 11 & & \\
\hline & $7-12$ & 11 & 11 & & \\
\hline & $13-24$ & 6 & 6 & & \\
\hline & $25-60$ & 12 & 12 & & \\
\hline & $61-$ & 18 & 18 & & \\
\hline & 平均 & 59.0 か月 & & & \\
\hline 三重癌 & 発生間隔（月） & 第 1 癌－第 2 癌（例） & 第 2 癌－第 3 癌（例） & 計 (症例数) & \\
\hline \multirow[t]{6}{*}{$\mathrm{n}=11$} & $0-6$ & 3 & 3 & 6 & \\
\hline & $7-12$ & 1 & 0 & 1 & \\
\hline & $13-24$ & 0 & 3 & 3 & \\
\hline & $25-60$ & 3 & 3 & $5 *($ 症例の 1 重複あり $)$ & \\
\hline & $61-$ & 4 & 2 & 6 & \\
\hline & 平均 & 64.1 か月 & 37.3 か月 & & \\
\hline 四重癌 & 発生間隔（月） & 第 1 癌一第 2 癌（例） & 第 2 癌一第 3 癌（例） & 第 3 癌－第 4 癌（例） & 計（症例数） \\
\hline \multirow[t]{6}{*}{$\mathrm{n}=3$} & $0-6$ & 1 & 1 & 1 & $1 * *($ 症例の 2 重複あり) \\
\hline & $7-12$ & 1 & 0 & 1 & $1 * * *($ 症例の 1 重複あり $)$ \\
\hline & $13-24$ & 0 & 0 & 0 & 0 \\
\hline & $25-60$ & 0 & 1 & 1 & 2 \\
\hline & $61-$ & 1 & 1 & 0 & 2 \\
\hline & 平均 & 35.0 か月 & 40.3 力月 & 22.3 か月 & \\
\hline
\end{tabular}

表 9 後発癌病期進行度

\begin{tabular}{|c|c|c|c|}
\hline 発生間隔（月） & 病 期 & 部位数 & 計 \\
\hline \multirow{5}{*}{$0-6$} & Stage I & 9 & \multirow{5}{*}{20} \\
\hline & Stage II & 3 & \\
\hline & Stage III & 5 & \\
\hline & Stage IV & 1 & \\
\hline & 不明 & 2 & \\
\hline \multirow{4}{*}{$7-12$} & Stage I & 3 & \multirow{4}{*}{14} \\
\hline & Stage II & 3 & \\
\hline & Stage III & 3 & \\
\hline & Stage IV & 5 & \\
\hline \multirow{4}{*}{$13-24$} & Stage I & 2 & \multirow{4}{*}{9} \\
\hline & Stage II & 1 & \\
\hline & Stage III & 4 & \\
\hline & Stage IV & 2 & \\
\hline \multirow{5}{*}{$25-60$} & Stage I & 4 & \multirow{5}{*}{20} \\
\hline & Stage II & 3 & \\
\hline & Stage III & 6 & \\
\hline & Stage IV & 5 & \\
\hline & 不明 & 2 & \\
\hline \multirow{5}{*}{$61-$} & Stage I & 3 & \multirow{5}{*}{26} \\
\hline & Stage II & 4 & \\
\hline & Stage III & 6 & \\
\hline & Stage IV & 10 & \\
\hline & 不明 & 3 & \\
\hline
\end{tabular}

$\mathrm{n}=$ 後発癌 89 部位

（第 2 癌 : 72 部位 第 3 癌 : 14 部位 第 4 癌 : 3 部位）
表 10 癌家族歴

\begin{tabular}{|c|c|c|c|}
\hline \multirow{8}{*}{$\begin{array}{l}\text { 癌家族歷あり } \\
\text { 二重癌 } n=58\end{array}$} & 23 例 & \multicolumn{2}{|l|}{$31.9 \%$ (23 例 $/ 72$ 例 $)$} \\
\hline & \multirow{2}{*}{\multicolumn{2}{|c|}{$\begin{array}{c}\text { 癌家族歴あり } 16 \text { 例 (27.6\%) } \\
\text { 内訳 同胞 } 1 \text { 人 }\end{array}$}} & \\
\hline & & & 7 例 \\
\hline & & 同胞 2 人 & 2 例 \\
\hline & & 両親 1 人 & 6 例 \\
\hline & & 両親 1 人と同胞 1 人 & 1 例 \\
\hline & 同一癌罹患 & 急家族歷あり & 3 例 \\
\hline & 内訳 & 胃癌 & 3 例 \\
\hline \multicolumn{4}{|l|}{ 三重癌 $n=11$} \\
\hline & \multicolumn{2}{|r|}{7 例 (63.6\%) } & \\
\hline & 内訳 & 同胞 1 人 & 4 例 \\
\hline & & 同胞 2 人 & 1 例 \\
\hline & & 同胞 3 人 & 1 例 \\
\hline & & 両親 2 人 & 1 例 \\
\hline & 同一癌罹患 & 患家族歷あり & 2 例 \\
\hline & 内訳 & 胃癌 & 2 例 \\
\hline
\end{tabular}


表 11 契煙歴, 飲酒歴, Brinkman index, Sake index

Brinkman index, Sake index

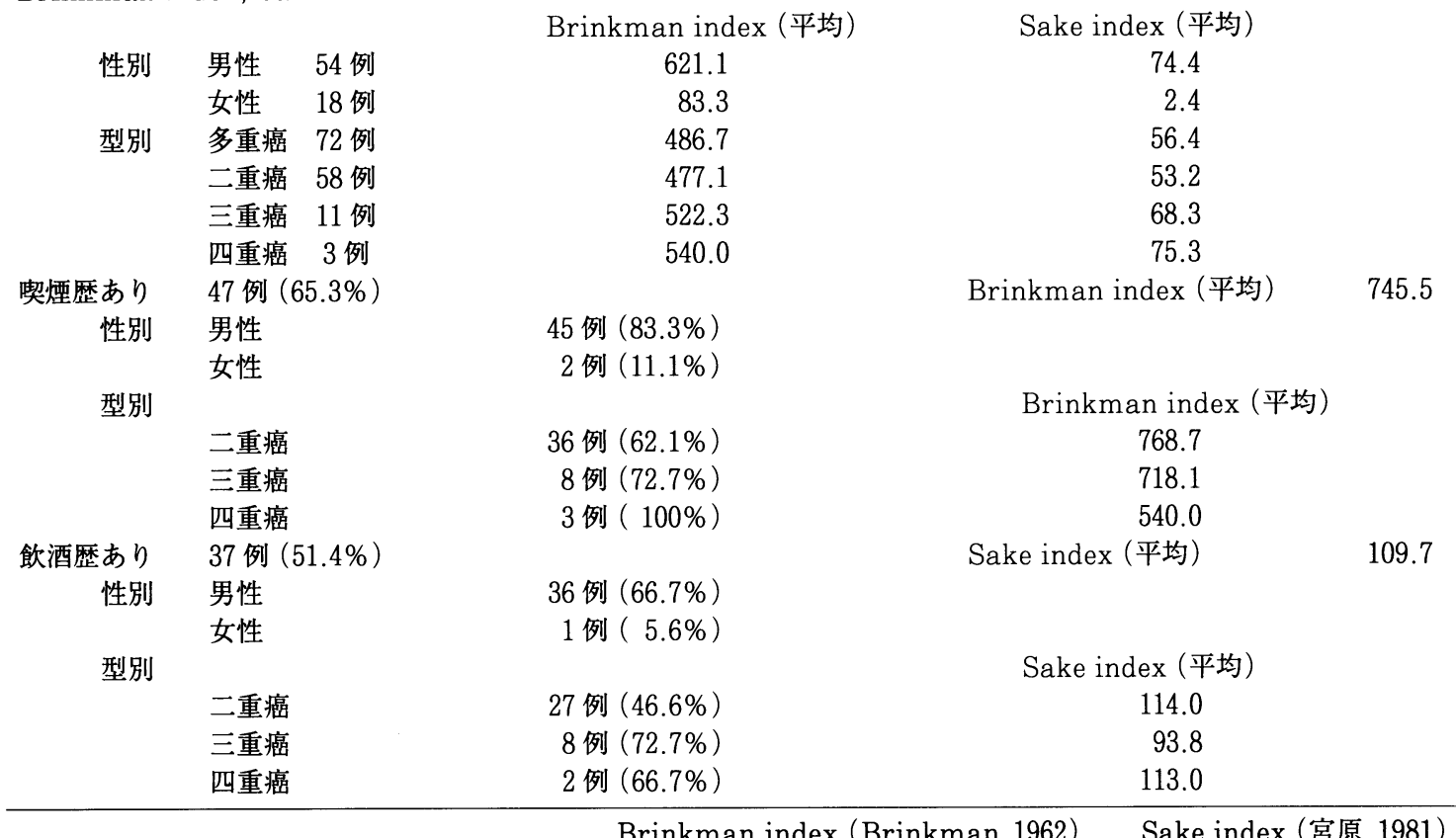

表 12 部位別喫煙飲酒状況

\begin{tabular}{lcccr}
\hline \multicolumn{1}{c}{ 位 } & 喫煙率 $\%$ & B.I. (平均) * & 飲酒率 \% & S.I. (平均) ** \\
\hline 舌 $(n=32)$ & $65.6(21 / 32)$ & 740.7 & $43.8(14 / 32)$ & 118.6 \\
口底 $(n=13)$ & $92.3(12 / 13)$ & 827.5 & $84.6(11 / 13)$ & 81.4 \\
煩粘膜 $(n=11)$ & $54.5(6 / 11)$ & 673.3 & $27.3(3 / 11)$ & 86.0 \\
軟口蓋 $(n=7)$ & $85.7(6 / 7)$ & 754.2 & $85.7(6 / 7)$ & 163.6 \\
下顎歯肉 $(n=5)$ & $40.0(2 / 5)$ & 740.0 & $40.0(2 / 5)$ & 74.0 \\
上顎歯肉 $(n=5)$ & $40.0(2 / 5)$ & 605.0 & $40.0(2 / 5)$ & 74.0 \\
硬口蓋 $(n=4)$ & $75.0(3 / 4)$ & 498.3 & $25.0(1 / 4)$ & 51.0 \\
胃 $(n=21)$ & $71.4(15 / 21)$ & 655.7 & $38.1(8 / 21)$ & 79.3 \\
食道 $(n=21)$ & $76.2(16 / 21)$ & 738.4 & $85.7(17 / 21)$ & 131.1 \\
大腸 $(n=6)$ & $83.3(5 / 6)$ & 708.0 & $50.0(3 / 6)$ & 71.0 \\
下咽頭 $(n=5)$ & $80.0(4 / 5)$ & 596.3 & $80.0(4 / 5)$ & 145.0 \\
肺 $(n=3)$ & $100(3 / 3)$ & 866.7 & $66.7(2 / 3)$ & 79.0 \\
喉頭 $(n=2)$ & $100(2 / 2)$ & 825.5 & $100(3 / 3)$ & 101.0 \\
\hline
\end{tabular}

* 喫煙者の平均 Brinkman index (Brinkman 1962)

**飲酒者の平均 Sake index（宮原 1981） $\mathrm{n}=$ 多重癌症例数

Stage I が 3 部位 (11.5\%), Stage II 14 部位 (53.8\%), Stage III 6 部位 (23.1\%), StageIVは 10 部位 $(38.5 \%)$ であった(表 9 ).

\section{5 . 危険因子}

1 ) 癌家族歴について

多重癌症例の癌家族歷を検討すると, 23 例 $(31.9 \%)$
に家族性が認められた. 特に二重癌症例においては 16 例 $(27.6 \%)$, 三重癌症例では 7 例 $(63.6 \%)$ で, 四重癌 症例には認められなかった。二重癌症例 16 例では同 胞 (兄弟姉妹) 1 人に認められたものが 7 例 $(43.8 \%)$ ， 同胞 2 人が 2 例 $(12.5 \%)$, 両親いずれか 1 人が 6 例 $(37.5 \%)$, 両親いずれか 1 人と同胞 1 人に認められた 
表 13 病理組織型

\begin{tabular}{|c|c|c|c|c|}
\hline 蛊 $\mathrm{n}=$ & & & & \\
\hline & 第 1 癌 & 第 2 澏 & 計（例） & \\
\hline & 扁平上皮癌 & 扁平上皮癌 & 22 & \\
\hline & 管状腺癌 & 扁平上皮癌 & 8 & \\
\hline & 扁平上皮癌 & 管状腺癌 & 5 & \\
\hline & 扁平上皮癌 & 腺癌 & 3 & \\
\hline & その他組み合わせ & & 20 & \\
\hline 三重癌 n=11 & & & & \\
\hline & 第 1 癌 & 第 2 癌 & 第 3 癌 & 計 (例) \\
\hline & 扁平上皮癌 & 扁平上皮癌 & 扁平上皮癌 & 3 \\
\hline & 扁平上皮癌 & 腺癌 & 扁平上皮癌 & 1 \\
\hline & 扁平上皮癌 & 乳頭腺管癌 & 扁平上皮癌 & 1 \\
\hline & 扁平上皮癌 & 非浸潤性乳管癌 & 浸潤性乳管癌 & 1 \\
\hline & 扁平上皮癌 & 管状腺癌 & 腺様輬胞癌 & 1 \\
\hline & 扁平上皮癌 & 扁平上皮癌 & 管状腺癌 & 1 \\
\hline & 不明 & 扁平上皮癌 & 扁平上皮癌 & 1 \\
\hline & 管状腺癌 & 腺癌 & 扁平上皮癌 & 1 \\
\hline & 扁平上皮癌 & 腺癌 & 管状腺癌 & 1 \\
\hline 四重癌 $n=3$ & & & & \\
\hline & 第 1 癌 & 第 2 癌 & 第 3 癌 & 第 4 癌 \\
\hline & 扁平上皮癌 & 扁平上皮癌 & 扁平上皮癌 & 管状腺癌 \\
\hline & 低分化型腺癌 & 扁平上皮癌 & 扁平上皮癌 & 扁平上皮癌 \\
\hline & 腺癌 & 管状腺癌 & 扁平上皮癌 & 乳頭状腺癌 \\
\hline
\end{tabular}

ものが 1 例 $(6.2 \%)$ であった. また同一癌の家族歴を 有したものが 3 例 $(18.8 \%)$ に認められ，いずれも胃 癌であった. 三重癌では同胞 1 人に認めたものが 4 例 $(57.1 \%)$, 同胞 2 人, 同胞 3 人, 両親共に認めたものが それぞれ 1 例 (各 $14.3 \%$ ) であった。さらに同一癌の 家族歴を認めたものが 2 例 $(28.6 \%)$ で,これも胃癌 であった（表 $10 ）$.

\section{2 ) 契煙歴, 飲酒歴について}

多重癌 72 例における喫煙歴, 飲酒歴を検討すると, 喫煙歴が 47 例 $(65.3 \%)$, 飲酒歴が 37 例 (51.4\%) に認 められた。このうち男性の喫煙歴, 飲酒歴はそれぞれ 45 例 $(83.3 \%), 36$ 例 $(66.7 \%)$ で, 女性ではそれぞれ 2 例 $(11.1 \%), 1$ 例 $(5.6 \%)$ であった。喫煙歴を多重癌 の型別にみると, 二重癌では 36 例 $(62.1 \%)$, 三重癌が 8 例 $(72.7 \%)$, 四重癌が 3 例 $(100 \%)$ に認められた. また飲酒歴は二重癌では 27 例 $(46.6 \%)$, 三重癌 8 例 $(72.7 \%)$, 四重癌 2 例 $(66.7 \%)$ に認められた。

Brinkman index ${ }^{14)}$ (以下 B. I.) および Sake index ${ }^{15)}$ （以下 S. I.）を算出すると, 契煙歴を有する 47 例では B. I. の平均值は 745.5, 飲酒歴を有する 37 例では S. I. の平均値は 109.7 であった。多重癌 72 例においては B. I. の平均值が 486.7, S. I. の平均値は 56.4 で, 男性 54 例では B. I. の平均値 621.1, S. I. の平均值は 74.4, 女性 18 例では B. I. の平均値が 83.3 , S. I. の平均値は 2.4 であった. また二重癌 58 例では B. I. の平均値が
477.1, S. I. の平均値は 53.2, 三重癌 11 例では B. I. の 平均値が 522.3, S. I. の平均値は 68.3 , 四重癌 3 例で は B. I. (平均) が 540.0, S. I. の平均値は 75.3 であっ た（表 11）.

発生部位別に喫煙飲酒状況を検討すると, 喫煙率の 高い部位は肺，喉頭が 100\%であり，次いで口底 $92.3 \%$, 軟口蓋 $85.7 \%$, 大腸 $83.3 \%$, 下咽頭 $80.0 \%$, 食 道 $76.2 \%$, 以下硬口蓋, 胃, 舌, 煩粘膜, 上下顎歯肉の 順であった．また飲酒率の高い部位は喉頭が $100 \%$ ， 次いで軟口蓋，食道が $85.7 \%$, 口底 $84.6 \%$,下咽頭 $80.0 \%$ であり, 以下肺, 大腸, 舌, 上下顎歯肉, 胃, 煩粘 膜, 硬口蓋の順であった。さらに喫煙者の B. I. の平 均値は, 肺が 866.7 と最も高く, 次いで口底 827.5 , 喉 頭 825.5 で, 以下軟口蓋, 舌, 下顎歯肉, 食道, 大腸, 煩 粘膜, 胃, 上顎歯肉, 下咽頭, 硬口蓋の順であった。ま た飲酒者の S. I. の平均値は, 軟口蓋が 163.6 と最も高 く, 次いで下咽頭の 145.0 , 食道 131.1 で, 以下舌, 喉頭, 煩粘膜, 口底, 胃, 肺, 上下顎歯肉, 大腸, 硬口蓋の順 であった(表 12).

\section{6. 病理組織型}

病理組織型においては, 扁平上皮癌が 105 部位 (65.2\%) で最も多く, 次いで管状腺癌 20 部位 $(12.4 \%)$ であった. 多重癌における病理組織型の組み合わせと しては, 扁平上皮癌同士の組み合わせが 31 例（43.1 
\%）に認められ，これを多重癌の型別に検討すると， 二重癌では 22 例 $(37.9 \%)$ ，また三重癌では 7 例 (63.6\%) に認められ，さらに四重癌では 2 例 $(66.7 \%)$ であった(表 13).

\section{考察}

近年顎口腔領域の重複癌に関する報告は増加してい るが，その解析法に関する問題点は，対象とする腫湯 の解剖学的部位の設定, 定義, さらに統計学的手法が 報告者により一定でないことである ${ }^{1213)}$. その理由 の一つは, 多施設間の情報の交換が不足し，共通のプ ロトコールに従った報告が少ないことである ${ }^{16)}$. 疫学 的研究においては, 従来の施設内癌登録資料を用いた hospital-based cohort study から，近年は population-based cohort studyによる疫学的研究 7,17) が散見されるようになってきた。後者は重複癌発生の 危険率を推定するために多くの症例を確保でき，症例 内容に偏りが少ない点が優れていると報告されてい る $^{17)}$. しかしこれらの研究には地域がん登録の状況に より地域格差が生じる危険性があるため, 現状におい てはその格差の是正と整備が急務である. 新潟県にお いても平成 3 年度より事業が発足したばかりであり， 今後のデータの蓄積が待たれるところである.

今回顎口腔領域に発生した癌を含む多重癌を， Warren \& Gates ${ }^{12)}$ の基準をもとに 72 例を検索抽出 した. 全悪性腫瘍患者 927 例に占める割合は $7.8 \%$ で あった. 本邦における多重癌の発生頻度に関する報告 は, 犬山ら ${ }^{18)}$ は $2.8 \%$, 川本ら ${ }^{7)}$ は $4.7 \%$, 喜多ら ${ }^{2)}$ は $6.97 \%$, 瀧田ら ${ }^{3)}$ は $4.3 \%$, 鹿嶋ら ${ }^{6)}$ は $11.22 \%$, 宮 原ら $\left.{ }^{9}\right)$ は $11.6 \%$ と報告している. また剖検例を含む全 悪性腫瘍症例を対象とした重複癌の発生頻度は, Warren ら ${ }^{12)}$ の $3.7 \%$, 馬場ら ${ }^{16)}$ の $3.1 \%$ などの報告 がある。一般に顎口腔領域における頻度はこれらより 高率とされている2〜6).

年次別発生頻度は, 前期 9 年間の発生頻度が $5.4 \%$ であったのに対し, 後期 9 年間は $10.2 \%$ と増加傾向を 示した. 経年的に重複癌は増加傾向にあると報告され ており 1,16), 馬場ら ${ }^{16)}$ はその要因として, 診断治療技 術の進歩, アフターケアの普及, 医療施設間の情報交 換の増加, 重複癌の概念の浸透, 発癌因子の増加など を指摘している。

多重癌を二重癌, 三重癌, 四重癌と型別分類したと ころ, 二重癌が $80.5 \%$ と最も多く, 三重癌以上の癌は 19.5\%であった. 三重癌以上の発生頻度については川 本ら ${ }^{7)}$ が $6.8 \%$, 喜多ら ${ }^{2)}$ が $7.7 \%$ と報告しており， 自験例においてはこれらより高い数値を示した.

多重癌症例における性差は, 前期において男女比が 4:1であったのに対し, 後期では 2.6:1 と男女差が 減少した.一方, 全悪性腫場患者においては, 全期間
を通して男女比に差がなく, 女性の多重癌症例が増加 していることが示唆された．従来顎口腔領域悪性腫 湯症例においては，男性にその発生頻度が高く，また 重複癌症例においても男性に多いと報告されてき た $5 \sim 7,19)$. 一方, Fitzpatrick ら20)は，口腔を含めた いわゆる上部消化管の重複癌発生の相対的危険率は, 男性 2.32 に対し女性 2.89 とむしろ女性に高率である と報告し, 同領域における重複癌症例の性差は今後変 動することが予想されると述べている。

第 2 癌の発生年齢を多重癌の発生年齢として検討を 行ったところ, 前期の平均年齢 58.2 歳が, 後期では平 均 63.3 歳で, 5.1 歳の増加をみた. 日本人の高齢化率 を考慮に入れても重複癌の発生年齢は年次的に高齢化 する傾向があるとされ16)，今回の検討でも同様の結果 であった

多重癌の発生部位としては, 顎口腔領域では舌，口 底が高い割合を示し，他領域では胃，食道が高い割合 を示した。さらに多重癌全体においては，口腔，下咽 頭, 喉頭, 食道, 肺といった管腔臓器において $68.3 \%$ を占めた.Vrabec 5 ${ }^{8)}$ は口腔, 咽頭, 喉頭, 食道, 肺 をいわゆる multicentric zone と定義し，頭頸部癌に 重複する癌が同領域内に発生したものは $65.1 \%$ を占め たと報告している。これらは Gluckman ら ${ }^{21)}$ の提唱 したいわゆる field cancerization の概念を反映する ものと考えられる.他領域における癌発生部位では食 道と並んで胃が多かったが，同様の報告も多く2 8)， 川本ら $\left.{ }^{7}\right)$ は発生期待値との比較を行い, 胃に関しては 単発癌の偶然の重複の結果でしかないと報告している. しかし, 自験例においては後発癌としての胃癌の発生 が 11 例に認められ，多重癌の存在を念頭に入れた経 過観察の重要性が示唆された ${ }^{11)}$.

また食道での発生が第 2 癌以降の後発癌に多く認め られた. 渡辺 ${ }^{22)}$ は先発癌と後発癌の臓器相関性につい て報告し, 消化器癌においては口腔癌は食道癌および 胃癌へ，また食道癌は胃癌へ，さらに胃癌は大腸癌へ と，上から下へといわゆる down stream の関係にあ ると述べている。

多重癌症例 72 例中 18 例 $25.0 \%$ に同時性発生が認め られた。この多重癌症例のうち $1 / 4$ に同時性癌が認 められたことの臨床的意義は大きく, 先発癌の診断に おいては, 多重癌の存在を念頭に入れて第 2 癌（後発 癌)の早期発見を目的に他葴器の検索の必要性があり， また治療直後においても十分な観察の必要があること を意味している11)。一方 61 か月以上の異時性におい ては 26 部位 $(29.2 \%)$ の癌発生が認められており, 病 期進行度も Stage III，IN $61.5 \%$ を占めるなど進行例 が多いことが特徵であった. 当科では顎口腔領域癌治 療後の定期検査において, 各種エックス線検查, CT, MRIに加え，腫瘍および骨シンチによる核医学診断 にて全身のスクリーニングを行い,さらに食道および 
喉頭の内視鏡的検査を追加し, 腫瘍マーカーの検索は ルーチンに行っている.

多重癌の発生間隔については, 第 1 癌 (先発癌) が 診断された時から第 2 癌 (後発癌) 診断までの期間と し, 発生間隔が 6 か月以内のものを同時性，6 か月以 上のものを異時性発生とした. これらの多重癌の発生 間隔は, 診断技術の進歩により短縮されるべきもので あり, さらに実際的には後発癌が発生してから診断さ れるまでには一定の期間があり, 腫晹の進展速度や性 質によっても影響を受ける。.また同時性癌においては, 後発癌の進行度によって実質的な癌の発生順位が逆転 する可能性も包含している. 臨床的に発癌の時期を明 確にとらえることが困難な現状においては, 発生間隔 の定義は臨床的な診断時期をもって決定せざるをえな いと考える.

一方, 同時性, 異時性の定義は臨床的な意義を第一 に考慮した上のものであるべきであり, 先発癌と後発 癌がそれぞれの治療，予後において影響を及ほしあう 可能性の高い期間を同時性と定義するのが適当と考え る. 著者が以前行った, 今回と同様な定義において後 発他領域癌に対する治療態度, 予後を検討した結果で は，異時性に比して同時性癌において，明らかに根治 的治療がなされる傾向が強く，予後が良好であった ${ }^{11)}$. 一般的には 1 年以内の発生間隔をもって同時性と扱わ れていることが多い $3,18,23)$ が，今後検討を要するも のと考える.

癌家族性について検討したところ, 多重癌症例の $31.9 \%$ に家族性が認められた.なかでも三重癌症例に おいて高率を示し, 多重癌における家族性発生が強く 示唆された. 大腸癌における家族性については共通遺 伝子の存在が従来より指摘されているが 1 ), 顎口腔領 域の悪性腫湯における報告は少ない.一方加藤ら ${ }^{24)}$ は 単なる癌家族歴の有無による調査では統計学的に有意 差は認められず，また家族内に癌患者が 1 人存在する といった状況においては, 死因の 4 分の 1 を癌が占め る現在では臨床的意義に疑問があると述べている。こ のように癌家族性発生のみが必ずしも遺伝的素因を反 映する訳ではなく，むしろ同胞などに多人数の癌患者 もしくは同一癌患者が認められる場合は, 同一家族内 における環境などの発癌因子についても今後検討すべ き必要性があると考える。

喫煙および飲酒に関する因子として，Brinkman index $^{14)}$ (B. I.) およびSake index ${ }^{15)}$ (S. I.) を算出 した. 多重癌症例 72 例の B. I. の平均は 486.7 , S. I. の平均は 56.4 であったが, 多重癌の型別で比較すると, 癌の重複数が増加するとともに B. I. および S. I. 值 は増加傾向を示した。

癌の発生部位別では, 喫煙率, B. I. の平均値共に高 值を示す傾向にあったのが口底で, 飲酒率, S. I. では 食道であった. また B. I., S. I. 共に高值を示す傾向に
あったのが軟口蓋であった。肺，下咽頭，喉頭は症例 数が少なく，さらに症例の蓄積が必要である. 宮原 ら ${ }^{15)}$ は発癌危険因子として喉頭癌における喫煙, 口腔 癌, 下咽頭癌, 中咽頭癌における飲酒を指摘し，それ ぞれに飲酒, 契煙が相加的関与を認めると報告してい る.また, 有池ら ${ }^{23)}$ は口底癌の重複癌が有意に多いこ とを指摘し, 発癌要因として, 他の口腔癌で多いとさ れる慢性の局所刺激ではなく，いわゆる field cancerization $^{21)}$ の関与が考えられるとしている.今 回の危険因子の検討でも口底のみがいわゆる口腔癌の 中で B. I. が高値であるなど, 他の口腔癌と異なって いた. 今回の検討結果では, B. I. が700 以上, S. I. が 100 以上の顎口腔領域癌患者に対しては軟口蓋, 口底, 食道といったいわゆる multicentric zone ${ }^{8)}$ に癌が同 時性あるいは異時性に発生しうることを念頭において 精査すべきと考えられた.

他の多重癌発生因子として諸家より指摘されている ものに, 先発癌に行われた化学療法, 放射線療法によ る誘発癌の問題がある. 吉本ら ${ }^{25)}$ の報告では, 乳癌手 術症例に対する Mitomycin-C 投与の及ほす影響に関 する調査で, 第 2 癌の発生には影響していなかったが, 一方寺沢ら ${ }^{26)}$ は胃癌手術症例に対する Tegaful や 5 $\mathrm{Fu}$ の長期にわたる術後補助化学療法の影響に関する 調査においては, 化学療法が第 2 癌の発生率を増加さ せる可能性があることを指摘している.また自験例 72 症例のうち, 放射線誘発癌の可能性があるものは 1 例 で,これは酒井ら 27) の確診度分類では B-1 に相当す る左右煩粘膜の口腔内多発癌症例であった.

病理組織型としては扁平上皮癌が最も多く，また病 理組織型組み合わせでは扁平上皮癌同士の重複が 43.1 \%を占めたが，この割合は三重癌以上において著明に 増加する傾向が認められた。これらは多重癌が部位的 にいわゆる multicentric zone ${ }^{8)} に$ 多く発生したこと にもよるが, 三重癌以上では同領域内での多中心性癌 が増加する可能性が示唆された。

同一組織型の組み合わせ, 特に扁平上皮癌同士の重 複においては, しばしば近接部位においては先発癌の 浸潤拡大, 再発と, 遠隔部位においては転移性腫瘍と の鑑別が問題となる ${ }^{28,29)}$. 同一臓器内もしくは同一上 皮を母地として発生した, いわゆる多中心性癌は, 臨 床的に腫瘍間の距離や画像診断および解剖学的な根拠 によっておのおのの原発性を鑑別されることが多いが， 今回の検討においては病理組織学的所見にも根拠を求 め, 原則として癌腫においては, 各腫瘍の境界部に, あきらかに正常粘膜上皮が介在していること，さらに おのおのの腫場の周囲組織への浸潤像があきらかに臓 器固有の粘膜上皮を発生母地として周囲へ浸潤した所 見を有し，その増殖の主座が上皮下にないことを確認 することにより判定した. 近年, パラフィンブロック より DNA を抽出し restriction enzyme fragment 
length polymorphismにより腫瘍クローンの独立性 の客観的証明が可能になり, 多重癌の研究にも応用し うる分野として注目されている22. 今後はこのような 分子生物学的な観点より判定基準の設定が望まれる。

\section{結語}

1975 年 1 月より 1992 年 12 月の 18 年間に, 当科およ び関連 4 医療施設を受診した顎口腔領域を含む多重癌 72 例に対し臨床的検討を加え, 以下の結果をえた.

1. 顎口腔領域悪性腫瘍患者 927 例のうち多重癌と 診断したものは 72 例で, その発生頻度は $7.8 \%$ であっ た。

2. 年度別発生頻度では対象期間の前半 9 年間の発 生頻度が $5.4 \%$ であったのに対し, 後半 9 年間は 10.2 \%と増加傾向を示した. また女性の多重癌症例の増加 が示唆された。

3. 多重癌の発生部位は, multicentric zone すなわ ち口腔, 咽頭, 喉頭, 食道, 肺 (気管支) などの管腔臓 器に $68.3 \%$ の高い発生がみられ，また他領域癌の発生 部位としては食道, 胃がそれぞれ $27.6 \%$ と高い割合を 示した.

4. 多重癌症例 72 例中 18 例 20 部位に後発癌同時性 発生を認め, 発見時の後発癌病期進行度では 9 部位 (45.0\%) が Stage I であった. また 61 か月以上の後 発癌異時性発生は 26 部位に認め, そのうち 16 部位 (61.5\%) がStage III，IVであった.

5 . 多重癌症例 72 例中, 癌家族歴を有するものが 23 例 $(31.9 \%)$, 㓶煙歴を有するものが 47 例 $(65.3 \%)$, 飲 酒歴を有するものは 37 例 $(51.4 \%)$ 認められた.

6.72 症例の Brinkman index ${ }^{14)}$, Sake index ${ }^{15)}$ の平均はそれぞれ 486.7, 56.4であった。

発生部位では, 喫煙率, B. I. の平均値共に高値を示 す傾向にあったのが口底で, 飲酒率, S. I. では食道で あった. また B. I., S. I. 共に高值を示す傾向にあった のが軟口蓋であった.

7. 病理組織学的検討では扁平上皮癌が $65.2 \%$ を占 め, 扁平上皮癌同士の重複が $43.1 \%$ に認められた。

稿を終えるにあたり，本研究の遂行にあたり想切なる ご指導をいただいた故加藤袞治教授のご冥福をお祈り申 し上げます.また多大な御協力をいただいた新潟県立が んセンター耳鼻咽喉科, 長谷川聡先生をはじめ各施設の 諸先生に厚くお礼申し上げます。

本論文の要旨は, 第 47 回日本口腔科学会総会 (1993 年 5 月 13 日弘前), 第 17 回日本頭顓部腫整学会 (1993 年 7 月 1 日東京), 第 48 回新潟癌治療研究会 (1994 年 2 月 19 日新潟), 第 39 回日本口腔外科学会総会 (1994 年 11 月 7 日名古屋）において発表した。

\section{引用 文 献}

1）関根 毅：重複癌とは. 臨床の立場から. 最新 医学 40: 1580-1587 1985.

2 ) 喜多みどり, 大川智彦, 他 : 頭頸部悪性腫瘍に おける重複癌症例の検討。臨放 29: 289-294 1983.

3）瀧田正亮, 谷口文章, 他 : 頭頸部悪性腫瘍にお ける重複癌症例の検討. 日口外誌 36: 1320-1326 1990.

4）浦出雅裕, 美馬孝至, 他 : 当科における重複癌 症例の臨床統計. 日口外誌 36: 2527-2530 1990.

5）鹿嶋光司, 有馬良治, 他 : 頭頸部癌患者におけ る重複癌の検討. 口科誌 42: 316-323 1993.

6）喜多みどり, 大川智彦 : 頭頸部腫場における重 複癌の臨床. KARKINOS $3:$ 985-991 1990.

7）川本誠一, 池田 恢, 他 : 頭頸部癌症例におけ る重複癌一重複部位・頻度など続計的考察一。 癌の臨床 28: 1 - 71982.

8) Vrabec, D.P.: Multiple primary malignancies of the upper aerodigestive system. Ann Otol 88: 846-854 1979.

9）宮原 裕, 佐藤武男, 他 : 頭頸部癌における重 複癌の実態と治療。癌の臨床 $36: 2529-2533$ 1990.

10）仲 博美, 石川紀彦, 他 : 頭䫟部領域の多発癌. 癌の臨床 36: 2404-2408 1990.

11）田中 彰, 土川幸三, 他 : 顎口腔領域における 重複癌症例の臨床的検討. 頭頸部腫瘍 20: 57-61 1994.

12) Warren, S. and Gates, O.: Multiple primary malignant tumors, a surgery of the literrature and a statistical study. Am. J. Cancer, 16: 1358-1414 1932.

13) Moertel, C.G., Dockerty, M.B., et al.: Multiple primary malignant neoplasms. I. Introduction and presentation of data. Cancer 14: 221-230 1961.

14) Brinkman, G.L., Coates, E.O.: The prevalence of chronic bronchitis in an industrial population. Am Rev Resp Dis 86: 47-54 1964.

15）宮原 裕, 佐藤武男：頭頸部悪性腫瘍の発癌要 因 (第 3 報) 一鿄煙, 飲酒の影響に関する臨床 的検討一. 日耳鼻 84: 233-238 1981 .

16）馬場謙介, 下里幸雄, 他 : 重複癌の統計とその 問題点. 癌の臨床 17: 424-436 1971.

17）岡本直幸, 森尾葚介, 他 : 重複癌発生の相対危 険. 癌の臨床 35: 348-354 1989.

18）犬山征夫, 斎藤成司, 他 : 当教室における重複 悪性腫瘍症例および本邦報告例の統計的観察. 日耳鼻 79: 189-202 1976.

19）相原隆一, 湯本英二, 他 : 頭頸部における重複 癌症例の検討. 日耳鼻 93: 381-387 1990.

20) Fitzpatrick, P.T., Tepperman, B.S.: 
Multiple primary squamous cell carcinoma in the upper digestive tract. Int $\mathrm{J}$ Radiat Oncol Biol Phys 10: 2273-2279 1984.

21) Gluckman, J.L., Crissman, J.D., et al.: Multicentric squamous cell carcinoma of the upper aerodigestive tract. Head \& neck surg 3: 90-96 1980 .

22）渡辺 昌: 多重がんの実態と要因. 癌と化学療 法 17: 967-973 1990.

23）有池栄一郎, 神宮賢一, 他 : 口底癌患者におけ る重複癌について. 口科誌 37: 654-659 1988.

24）加藤育子, 富永祐民：重複癌の疫学一癌登録よ り. 最新医学 40: 1588-1592 1985.

25）吉本賢隆, 坂本吾偉, 他 : 乳癌重複癌の発生に
及ほす癌家族歴・放射線照射・化学療法の影響. 癌の臨床 30: 1361-1368 1984.

26）寺沢幸男, 佐々木迪郎：重複癌発生と長期化学 療法一胃癌手術症例の検討から一。 日癌治 22 : 1111-1116 1987.

27）酒井邦夫, 日向 浩, 他 : 放射線治療後の発癌 に関する全国調查成績. 日本医放会誌 41: 24-32 1981.

28）土川幸三, 加藤譲治, 他 : 顎口腔領域悪性腫瘍 に関連する重複癌症例の臨床的 - 病理学的検討. 歯学 77: 1318-1326 1989.

29）佐藤 光, 岡野篤夫, 他 : 顎口腔領域への転移 腫瘍 10 例についての検討. 頭頸部腫瘍 20 : 71-77 1994 . 